\title{
Embriaguez e força plástica no texto de João Guimarães Rosa.
}

\author{
João Batista Santiago Sobrinho
}

Resumo:

Este estudo estabelece uma relação de equivalência entre as expressões irrealidade, faz-de-conta e temulência, contidas no texto de João Guimarães Rosa, com os conceitos de embriaguez dionisíaca e força plástica do poeta e filósofo alemão Friedrich Wilhelm Nietzsche.

Palavras-chave: irrealidade, faz-de-conta, temulência, embriaguez, forçaplástica.

No capítulo "Linguagem e revelação", do livro Guimarães Rosa, Assis Brasil (1969, p. 19)afirma que ao "designar o terceiro prefácio de Tutaméia de Nós, os temulentos, João Guimarães Rosa quis nos dar a sua 'visão' de mundo, através da 'embriaguez' provocada ou não de seus habitantes".

Paulo Ronái, por seu turno, afiança que "Nós, os temulentos"

deve ser mais que simples anedotas de bêbedo, como se nos depara. Conta a odisséia que para um borracho representa a simples volta para casa. Porém os embates nos objetos que lhe estorvam o caminho envolvem-no em uma sucessão de prosopopéias, fazendo dele, em rivalidade com esse outro temulento que é o poeta, um agente de transfigurações do real. (RÓNAI apud ROSA, 1976, p. 196)

E, finalmente, o crítico Benedito Nunes (1976, p. 208) considerando a embriaguez de "Nós, os temulentos", afirma que essa é a

saída para o drama do estar-no-mundo - drama permanente, por certo - a bebedeira alcoólica é somente a manisfestação ostensiva da geral temulência humana, da embriaguez, que múltiplas formas tem - da euforia dos coribantes à mania de que Platão trata no Fedro, do amor-paixão a loucura, da possessão criadora à infinitude do desejo".

Dos três autores citados acima, destaca-se o fato de concordarem que o prefácio é uma espécie de teoria da embriaguez. Nunes ressalta as múltiplas formas da embriaguez com lastros na antiguidade e liga o prefácio "Nós, os temulentos" à possessão criadora, dimensão que o périplo de Chico alegoricamente encarna. A temulência experienciada pelo herói Chico é análoga à embriaguez dionisíaca teorizada pelo poeta e filósofo alemão Nietzsche em seu livro $O$ nascimento da tragédia. Temulência que, ademais, comporta ainda aproximações com o conceito de força plástica, que se encontra na "II consideração intempestiva sobre a utilidade e os 
inconvenientes da História para a vida", do livro Escritos sobre a História (NIETZSCHE, 2005).

Segundo o filósofo Roberto Machado (2005, p. 7), "os conceitos de apolíneo e dionisíaco, [são] elaborados a partir das categorias metafísicas de essência e aparência ou, mais precisamente, da dualidade schopenhauriana vontade e representação". Apolo, deus solar, liga-se ao brilho e a aparência. Conceber um mundo brilhante "significa não só criar uma proteção contra o sombrio, o tenebroso da vida, mas sim criar um tipo específico de proteção: a proteção pela aparência".

$\mathrm{Na}$ relação de Nietzsche com a metafísica schopenhauriana, figura-se numa direção estética. Para o poeta filósofo a existência e o mundo justificam-se apenas como fenômenos estéticos. Nietzsche traduz o trágico a partir do espírito da música advindo da tragédia ática.

A proteção contra o drama quotidiano de estar-no-mundo, no prefácio "Nós, os temulentos", figura-se por intermédio da "transfiguração do real", provocada pela aparência, a qual ele chama de irrealidade. "De sobra afligia-o a corriqueira problemática quotidiana, a qual tentava, sempre que possível, converter em irrealidade" (ROSA, 1967, p. 101). A irrealidade, por sua vez, é proporcionada pela temulência absorvida na via-sacra alcoólica realizada pelo trágico herói-protagonista Chico, cujo périplo - nóstos, retorno ao lar - permite uma analogia com a embriaguez dionisíaca, estado fisiológico, do qual, segundo Nietzsche, o artista se vale para criar, isto é, viver. A irrealidade, conferida ao herói Chico pelo narrador, compreende um fenômeno estético. Este herói é trágico, porque ele comporta em seu itinerário as etapas apolíneo-dionisíacas pelas quais passa um herói trágico. Nietzsche nos faz ver que à ruptura do apolíneo - princípio de individuação - sucede a comunhão perigosa com o êxtase incitado pela embriaguez dionisíaca e, finalmente, o despedaçamento, isto é, a morte, que leva ao reencontro com a natureza ou com o Uno. Já a união entre Apolo e Dioniso significaria, ao mesmo tempo, para Nietzsche, um dizer sim à vida.

Em que pese a fortaleza do princípio de individuação apolíneo, seu fundo é dionisíaco. O apolíneo não passa de uma máscara, uma aparência do dionisíaco. Segundo Nietzsche (2001, p. 69-70),

o único Dioniso verdadeiramente real aparece numa pluralidade de configurações, na máscara de um herói lutador e como que enredado nas malhas da vontade individual. Pela maneira como o deus aparecente fala e atua, ele se assemelha a um indivíduo que erra, anela e sofre: e o fato de ele aparecer com tanta precisão e nitidez épicas é efeito de Apolo oniromante que interpreta para o coro o seu estado dionisíaco, através daquela aparência similiforme, na verdade é o Dioniso, sofredor dos Mistérios, aquele deus que experimenta em si os padecimentos da individuação, a cujo respeito mitos maravilhosos contam que ele, sendo criança, foi despedaçado pelos titãs e que agora, nesse estado, é adorado como Zagreus: com isso se indica que tal despedaçamento, o verdadeiro sofrimento dionisíaco, é como uma transformação em ar, terra, água e fogo, que devemos considerar, portanto, o estado da individuação, enquanto fonte e causa, individual de todo sofrer, como algo em si rejeitável.

O herói Chico é este indivíduo "sofredor dos mistérios" que "erra, anela e sofre". Ante o inefável, ele vai de "ziguezague" e vem de "zaguezigue" (ROSA, 1967, p. 104). 
A conversão do quotidiano em irrealidade, realizada por intermédio da alegria temulenta, caracteriza no herói Chico, máscara de um outro temulento, o poeta João Guimarães Rosa. Chico configura uma encarnação do pugilato realizado pelos impulsos apolíneo e dionisíaco como reação ao "conflito essencial e drama talvez único de estarno-mundo" (ROSA, 1976, p. 101). Segundo Nietzsche (2001, p. 29), "esta alegre necessidade da experiência onírica é expressa por Apolo", enquanto o dionisíaco

é trazido a nós, o mais perto possível pela experiência da embriaguez. Seja por experiência da beberagem narcótica, da qual todos os povos e homens primitivos falam em seus hinos, ou com a poderosa aproximação da primavera a impregnar toda a natureza de alegria, despertam aqueles transportes dionisíacos, por cuja intensificação o subjetivo se esvanece em completo autoesquecimento. (2001, p. 30)

A irrealidade no prefácio "Nós, os temulentos" é espécie de recado apolíneo do autor Guimarães Rosa, como antídoto plasmador para esse drama inerente ao estarno-mundo. Libertar-se deste drama, através da irrealidade, é uma das propostas "chave" professada não só em Tutaméia, mas em todo texto rosiano. Esse sentido de libertação, o observamos, por exemplo, na idéia de faz-de-conta proposta pelo personagem Man'Antôno, do conto "Nada e nossa condição", de Primeiras Estórias. "Ao revés, porém, Man'Antônio concebia. - "Faça-se de conta!" (ROSA, 1969, p. 83). Contra os reveses da vida, ou seja, da história, "faça-se de conta".

Por outro lado, a resistência ao quotidiano pela irrealidade e o faz-de-conta, protagonizados respectivamente pelo herói apolíneo-dionisíaco Chico e pelo místico Man'Antônio, estão, ao mesmo tempo, em analogia com o conceito de força plástica de Nietzsche, utilizado reiteradamente em nossa tese intitulada $A$ embriaguez como força plástica da escritura: tramas além do bem e do mal entre João Guimarães Rosa e Nietzsche (SANTIAGO SOBRINHO, 2007). Nietzsche salienta a importância da estória e critica a pretensa objetividade cientificista da história, colocando em suspeita a compleição historicista típica de sua época. Nesse contexto, o filósofo poeta fala da

força plástica (plastische Kraft) do indivíduo, do povo ou da cultura em questão, quer dizer, esta força que permite a alguém desenvolver-se de maneira independente, transformar e assimilar as coisas passadas ou estranhas, curar as suas próprias feridas, reparar as suas perdas, reconstituir por si próprio as formas destruídas. (NIETZSCHE, 2005a, p. 73)

Transformar o mundo em irrealidade ou faz-de-conta não é senão fazer uso da força plástica a que se refere Nietzsche (2005a, p. 75), que diz:

a faculdade de ignorar até certo ponto a dimensão histórica das coisas como sendo a mais importante e a mais profunda das faculdades, pois nesta faculdade reside o único fundamento sobre o qual pode crescer algo de bom, saudável e grande, algo verdadeiramente humano.

A irrealidade na escritura rosiana é valorização estética da estória: uma outra maneira de dizer o que, aliás, é tematizado desde Sagarana - livro de estréia do autor - no conto "A hora e a vez de Augusto Matraga", no qual narra-se a estória de Augusto Estêves das Pindaíbas, um bandido terrível que, após uma surra mortal, numa virada surpreendente, sobrevive e converte-se problematicamente ao bem, com intuito de ascender ao céu "nem que seja a porrete" (ROSA, 1994, p. 442). Nesse sentido, o narrador afirma: "E assim se passaram pelo menos seis ou seis anos e meio, direitinho 
deste jeito, sem tirar e nem pôr, sem mentira nenhuma, porque esta aqui é uma estória inventada, e não é um caso acontecido, não senhor" (ROSA, 1994, p. 443).

Esta provocação à história será radicalizada no livro Tutaméia. No início do prefácio "Aletria e hermenêutica", o autor faz uma apologia da estória, enquanto critica a história, com a qual, a rigor, nunca rompeu: "a estória não quer ser história. A estória, em rigor, deve ser contra a História. A estória, às vezes, quer-se um pouco parecida à anedota" (ROSA, 1976, p. 3). Dessa forma, o autor desautoriza a feição rígida e esclarecida da história pulverizando-a em favor da maleabilidade paródica da estória, como "canto paralelo" (CAMPOS, 2005, p. 74), advindo da memória e do esquecimento: forças inerentes e importantes à vida.

Conjeturando sobre estória e história, Nietzsche (2005, p. 73) afirma que é "absolutamente impossível viver sem esquecimento". Chico afirma que bebe para "esquecer" (ROSA, 1976, p. 102). O esquecimento seria uma forma de abolição da história. Em seu livro Genealogia da moral, Nietzsche (2005b, p. 47-48) assevera que o esquecimento é uma forma de saúde: não poderia haver "felicidade, jovialidade, esperanças, orgulho, presente, sem o esquecimento".

Já em Ave palavra, livro póstumo, no conto "Do diário de Paris", almoçando com uma amiga, tomando vinho "Sancerre fruité" e ouvindo música basca, Guimarães Rosa (1985, p. 86) define o teatro como uma teofania: "- O que tudo resolve é o teatro. Amo o teatro. É um antigo amor que é de todos os gregos que eu conheço. Não é o teatro uma verdadeira teofania?" Lembremos que teofania (manifestação de Deus, coisa ou pessoa) se refere a vários deuses que pertencem a este mundo, entre eles, certamente, Dioniso e Apolo. Guimarães Rosa, ao que parece, propõe um entre-lugar teofânico para sua escritura, localizado entre a estória e a história. No conto "Pirlimpsiquice" de Primeiras Estórias, é encenado o drama "Os filhos do doutor famoso" encontra-se matéria de semelhante reflexão. Em certo momento, o narrador do conto diz: "já entre nós é a nossa 'estória', que, às vezes, chegávamos a preferir, à outra, a 'estória de verdade' do drama" (ROSA, 1969, p. 41). Na mesma narrativa, o personagem Perdigão, depois do trecho acima, diz: "-Representar é aprender a viver, além dos levianos sentimentos, na verdadeira dignidade" (ROSA, 1969, p. 41). Assim, vida e texto são equivalentes ou pelo menos se interpenetram.

No prefácio "Nós, os temulentos", quando seu narrador diz: "isto, a pifar, virar e andar, de bar a bar" uma repetição do substantivo "ar". É o "ar", como metáfora da vida, que busca Chico em sua via sacra temulenta. Para Chico o oxigênio é o quotidiano transfigurado em arte no fundir-se pelos campos da estória. O mesmo ocorre com o narrador, médium do escritor, para quem o oxigênio a literatura, a (ar)te de inventar, do latim (ars), plasticamente as formas degradadas.

Existem poucos estudos críticos sobre o prefácio "Nós, os temulentos", talvez, em virtude de seu viés tutaméico, quer dizer, de sua expressão descontraída de escritura paródica - como colagem de piadas requentadas - seja ele visto de um modo "menor". Mas o prefácio desconserta-nos confirmando, literalmente, uma força no processo criativo do autor: a embriaguez ou seu correlato, a temulência, como impulso vital ao itinerário do artista e de sua escritura. Contudo, não como uma proposição cuja causa final levaria ao paraíso; pelo contrário, a "graça" da temulência se revela no trânsito. O "fim" trágico, como sabemos, é sempre a morte, o amisturamento com o 
Uno. Chico termina o seu périplo temulento no momento em que "tumbou-se pronto na cama; e desapareceu de si mesmo" (ROSA, 1976, p. 104).

Assim, transformar-se em irrealidade, por intermédio da temulência, como embriaguez dionisíaca, não deixa de ser a força plástica que dá corpo ao suceder do artista Guimarães Rosa como a seus personagens.

Abstract:

This paper establishes a relationship of equivalency between the expressions unreality, "faz de conta" (make believe) and "temulência" (inebriety), which are found in the works of Guimarães Rosa, and the Dionysian ecstasy and plastic force concepts of the philosopher and poet Friedrich Nietzsche.

Keywords: unreality, make believe, inebriety, ecstasy, plastic-force.

Referências

BRASIL, Assis. Guimarães Rosa. Rio de Janeiro: Organizações Simões Editora, 1969.

CAMPOS, Haroldo de. Deus e o diabo no Fausto de Goethe. São Paulo: Perspectiva, 2005.

MACHADO, Roberto. Nietzsche e a polêmica sobre o nascimento da tragédia. Rio de Janeiro: Zahar, 2005.

NIETZSCHE, Friedrich Wilhelm. O nascimento da tragédia: ou helenismo e pessimismo. São Paulo: Companhia das Letras, 2001.

Escritos sobre a história. Rio de Janeiro: Ed. PUC-Rio, 2005a.

2005b.

Genealogia da moral: uma polêmica. São Paulo: Companhia das Letras,

NUNES, Benedito. O dorso do tigre. São Paulo: Perspectiva, 1976.

ROSA, João Guimarães. Primeiras estórias. Rio de Janeiro: J. Olympio, 1969.

ROSA, João Guimarães. Tutaméia. Rio de Janeiro: J. Olympio, 1976.

Fiç̧ão completa. Rio de Janeiro: Nova Aguilar, 1994.

Ave palavra. Rio de Janeiro: Nova Fronteira, 1985. 